\title{
GENDERED APPEARANCE NORMS: AN ANALYSIS OF EMPLOYMENT DISCRIMINATION LAWSUITS, 1970-2008
}

\section{Mary Nell Trautner and Samantha Kwan}

\begin{abstract}
The formal and informal regulation of employees' appearance is a routine component of organizational life. In our research, we analyze appearancerelated employment discrimination lawsuits. These cases involve organizational dress codes, grooming policies, and employers' attempts to regulate employees' appearance with regard to weight, hairstyles, religious attire, body art, and more. Men and women who refuse to comply with appearance norms face termination of their employment, promotion denials, lower wages, transfers, not being hired in the first place, and other workplace sanctions. Our focus on court deliberations and decisions allows us to explore not only the gendered nature of appearance policies themselves but also how the legal system supports, reinforces, codifies, or, conversely, deems unacceptable such policies. Our data demonstrate that organizations and courts are likely to support appearance norms that reinforce traditional ideas about femininity and masculinity.
\end{abstract}

Gender and Sexuality in the Workplace

Research in the Sociology of Work, Volume 20, 127-150

Copyright $(C) 2010$ by Emerald Group Publishing Limited

All rights of reproduction in any form reserved

ISSN: 0277-2833/doi:10.1108/S0277-2833(2010)0000020009 
A wide body of research examines how seemingly neutral organizational policies create and reinforce stereotypes and inequalities based on gender (e.g., Acker, 1990; Britton, 2000), as well also those related to class, race, and sexual orientation (see Britton \& Logan, 2008, for a review). Scholars have discovered such stereotypes and inequalities stemming from a wide range of organizational policies, including job definitions (Acker, 1990; Pierce, 1995), wage structures (Acker, 1990; Roth, 2006), maternity policies (Guthrie \& Roth, 1999), and promotions (Acker, 1990; Williams, 1992), among others. In this chapter, we analyze a different kind of organizational policy workplace regulations of employees' personal appearance - to examine the ways in which organizations create and reinforce stereotypes that are gendered, raced, classed, and sexualized. We also take a different approach to our analysis of these policies. We do not study the policies themselves or workers' lived experiences of gendered organizational policies. Instead, we analyze some employees' resistance to organizational appearance norms and policies through an examination of appearance-related employment discrimination lawsuits. By examining legal outcomes of these lawsuits, we have an opportunity to explore not only the gendered nature of appearance policies themselves but also how such policies are supported, reinforced, codified, or, conversely, deemed unacceptable by the legal system.

Grooming or appearance policies rely on and reproduce stereotypes and inequalities based on gender, race, class, and sexual orientation. Because Western culture is generally preoccupied with appearance, employers have an interest in how their employees appear to the general public. Thus, the policies they design are often informed by popular stereotypes and norms of attractiveness, femininity, and masculinity. Sometimes, these stereotypes are explicit, as when employers require women to wear high heels or allow men to have visible tattoos but not women. Sometimes, stereotypes embedded in organizational policies are more subtle, as in the early 2000s, when clothing chain Abercrombie \& Fitch allegedly terminated or transferred to less visible positions workers who did not fit A \& F's "all-American look" (Hurley-Hanson \& Giannontonio, 2006). Employees successfully sued, resulting in a $\$ 40$ million consent decree and a change in Abercrombie's hiring practices.

In general, employers are legally allowed to regulate whether a working body complies with an organization's overall image or the expectations they have of their employees' physical appearance. These employer regulations or policies range from mandating uniforms or certain modes of dress to proscribing certain hair styles or hair lengths, to formally or informally regulating employees' body shapes and sizes, to simply not hiring, not 
promoting, or firing individuals whose appearance does not conform to an employer's ideas about attractiveness, femininity, or masculinity. Because there are no federal protections against discrimination based specifically on appearance, employees who wish to file claims against their employers must use more general discrimination protections to make their case.

To varying degrees of success, employees have made appearance discrimination claims based on constitutional challenges arguing that particular appearance policies or regulations violate their constitutional rights to free expression, speech, or liberty (see Avery \& Crain, 2007; Rhode, 2009); Title VII claims of discrimination based on sex, race, or religion; disability discrimination claims under the Americans with Disabilities Act (ADA) (in the appearance realm, many of these challenges are obesity/overweight cases); and to a lesser degree, age discrimination claims under the Age Discrimination in Employment Act (ADEA).

The most often invoked piece of legislation for appearance discrimination claims is Title VII of the 1964 Civil Rights Act, designed to protect workers against sex, race, and religious discrimination in hiring and employment. There are two dominant arguments that workers can make with respect to Title VII: (1) that particular policies or regulations treat employees differently based on race, sex, religion, or national origin or (2) that particular policies or regulations that seem neutral on their face have a disparate impact on a specific sex, race, religious group, or people of a national origin, such as when police or fire departments impose a minimum height requirement that ends up having a disparate impact on women.

Below, we review sociological studies of femininity and masculinity in the workplace, as well as some of the previous research on organizational appearance policies. We then discuss our data and methods before turning to our findings which demonstrate that, over the past 40 years, federal courts have not only reinforced appearance norms, but they have reinforced gendered appearance norms.

\section{GENDER AND APPEARANCE IN THE WORKPLACE}

A large body of research demonstrates institutional advantages in the workplace for individuals who conform to aesthetic and other cultural ideals, including hegemonic ideals of femininity, masculinity, and attractiveness (for a recent summary, see Kwan \& Trautner, 2009). A consistent finding in this literature is that women especially are held accountable to numerous appearance norms, including, among others, those related to their 
hair, makeup, body size and shape, and clothing (Chapkis, 1986; Gimlin, 1996; Weitz, 2001). The basic assumption that underlies all of these norms is that women's bodies must be altered in some way - that their natural state is unacceptable. When women do not conform (or attempt to conform) to these norms, they face the possibility of sanctions in both their personal and professional lives. For example, Dellinger and Williams (1997) find that wearing makeup elicits several benefits for women in the workplace, including being perceived as being well rested and having an overall healthy appearance. When women who usually wear makeup show up to work without it, they are questioned by others about their health and/or energy level. Likewise, women who usually did not wear makeup to work received positive attention on those occasions when they did. Women in their study also felt that wearing makeup at work increased their perceived competence and credibility. Wearing makeup for them was seen as part of "looking professional." Young women can use makeup to try to look older (and thus more credible), older women can use makeup to appear younger (and thus more competent), lesbians can wear makeup to pass for straight, and women of color can use makeup to signal that they "fit in" with the norms of the dominant culture.

Similarly, women feel that their hair conveys messages to others in the workplace about their own competence, professionalism, and credibility (Weitz, 2001). Weitz found that many women feel a tension between femininity and professionalism and often cut their long hair short to appear more mature and competent and less "girly" (2001, p. 678). Other women rely on longer hair to convey messages about their professionalism, as did one of the lesbian women in Weitz's sample, who felt that her long hair helped her to "pass" as heterosexual, which she felt had helped her to gain benefits and avoid sanctions in the workplace.

Men are also required to enact "masculine" selves at work (Quinn, 2002; Schrock \& Schwalbe, 2009), and appearance is a key way in which masculinity can be performed (Pope, Phillips, \& Olivardia, 2000; West \& Zimmerman, 1987). Dozier (2005) found in her study of female-to-male (FTM) transsexuals, for example, that conformity to masculine norms and ideals in terms of facial hair, musculature, and other bodily signifiers was an important element in how transmen were able to establish credibility and competence at work.

Beyond these sorts of informal and interactional rewards that men and women can reap in the workplace, studies also show that both men's and women's conformity to hegemonic ideals of masculinity and femininity has a measurable impact on many stages of the employment process including 
hiring, wages, performance evaluation, and promotion (Hammermesh \& Biddle, 1994; Hosoda, Stone-Romero, \& Coats, 2003). Thus, individuals do not just work as people, they work as gendered people. And as others have shown, they work as raced, classed, and sexualized people as well (see Britton \& Logan, 2008, for a review).

While these and other studies tell us a lot about how norms of femininity, masculinity, and beauty affect workers and workplaces, few studies have examined actual organizational policies regarding employees' appearance, and those that have done so tend to come from legal scholars, not sociologists. These legal analyses tend to be normative in nature (i.e., "the law should change," e.g., Rhode, 2009), or small in scope, focusing on the legal decision made in one particular case (e.g., Avery, 2007; Pizer, 2007) or on decisions or policies regarding one aspect of appearance (e.g., McEvoy, 1992, focusing on obesity discrimination).

The formal and informal regulation of employees' appearance is a routine component of organizational life. Like Anne Hopkins who was denied partnership at her accounting firm because she was not feminine enough (Price Waterhouse v. Hopkins, 490 U.S. 228, 1989); Darlene Jespersen, a bartender who was fired for refusing to wear makeup (Jespersen $v$. Harrah's Operating Co., Inc., 444 F.3d 1104, 2006); or Ronald McConnell, who was fired when he refused to cut his long hair (McConnell v. Mercantile Nat. Bank at Dallas, 389 F.Supp. 594, 1975), men and women who do not conform to appearance norms or formal organizational policies may experience non-hiring, promotion denials, transfers, dismissal, and other workplace sanctions. What happens, however, when employees challenge what they experience as discriminatory actions by employers? In this chapter, we examine appearance-related employment discrimination lawsuits. We expand previous lines of inquiry by examining a large number and a wide range of appearance cases over a nearly 40-year period. We document the types of cases that workers have brought before the courts, how they have changed over the years, and their legal outcomes. Finally, we discuss the significance of these types of cases and their legal outcomes to the larger body of research on femininity and masculinity in the workplace, and discuss implications for future research.

\section{METHODS AND DATA}

To address these questions, we analyze 201 appearance-related employment discrimination lawsuits that were brought into federal courts between 1970 
and 2008 and reported in the Westlaw legal database. We start with 1970 because that is the first year an appearance-related employment discrimination case appeared in the federal courts; we did not impose this start date on the data. We did, however, impose 2008 as the ending year because our data collection took place in 2009 and we would not have been able to include cases spanning the full calendar year. We began by searching the Westlaw federal case database for all cases which alleged some sort of employment discrimination related to appearance. Along with Lexis, Westlaw is one of the major online legal databases used by both legal practitioners and academics. Using very broad search terms ${ }^{1}$ in order to cover nearly every aspect of appearance we were able to think of, ${ }^{2}$ our initial search yielded 988 cases. Together for the first 100 cases to establish coding and elimination rules and reliability, and then separately after that, we read through the synopsis and digest fields of all cases and eliminated those which were duplicates and those which were not actually appearance discrimination cases (often times a search term was used in ways that did not relate to appearance, for example, an employee's allegation that he/she was "pretty good" at something or a claim that an argument or decision "had no teeth"). This process of culling resulted in a final dataset of 201 cases.

While the exhaustiveness of our dataset rests in large part on our search terms, we believe that this dataset is comprehensive. First, we used a broad array of search terms. Second, we also included all cases that were formally coded by Westlaw under the 78k1177 category (Civil Rights - Employment Practices - Personal appearance; hair and grooming). Finally, we erred on the conservative side and included all cases remotely relating to appearance. For example, while we do not report here specific analyses on cases that have to do with height (e.g., cases where plaintiffs did not reach a height requirement) or weight (e.g., obesity cases that often invoked a medical disability discrimination charge), these cases were included in our dataset.

After gathering the full text of each case decision (including each case's full history, which for some cases meant gathering the full text of up to 12 separate judicial decisions), we worked jointly to code these cases over three passes. In the first pass, we read through cases for information on the race and gender of the plaintiff, the general dimension of discrimination under question, and the outcome of the case. In the second and third passes of coding, we added variables for which to search and refined those with which we started. We also had a research assistant code any new variables as needed such as, among others, the male-to-female (MTF) or FTM code for transgendered plaintiffs, the industry code, and employee's occupation code. Our final list of variables included many case descriptors such as start and 
finish year, final court in which the case was heard, state where case originated, whether the case involved the Equal Employment Opportunity Commission (EEOC), the main piece of legislation invoked by the plaintiff, and more. However, for the present analysis, we focus on the following variables:

Plaintiff's Gender: Based on textual information in the cases, we were always able to code for gender using the following categories - man, woman, transgender, and both men and women (with class suits). Within the transgender category, we were also able to identify if a plaintiff was MTF or FTM. Case decisions almost always referred to the plaintiffs as men or women (or transitioning/transitioned men or women) and used genderbased pronouns such as "she" or "he" to refer to the plaintiff(s).

Plaintiff's Occupation: We coded each plaintiff's occupation (or group of plaintiffs when they were of the same occupation) by type of employment, namely managerial and professional; service, clerical/administrative, sales workers, and related occupations; and blue collar workers such as truck drivers, maids, and mechanics. A case was coded as "multiple" if there were multiple employees working in different occupational tiers.

Key Appearance Dimension(s): We coded each case according to its key appearance dimension including (1) obesity/overweight (i.e., plaintiff alleging discrimination based on being too heavy); (2) minimum weight (i.e., plaintiff alleging discrimination based on not being heavy enough); (3) height (nearly every height case dealt with not being tall enough); (4) facial hair (e.g., beards, sideburns, or moustaches); (5) head hair (e.g., hair length, color, or style); (6) clothing (e.g., shirts, pants, dresses, skirts, or shoes); (7) accessories (e.g., buttons, pins, jewelry, ties, or piercings); (8) tattoos; (9) makeup (i.e., cosmetics including fingernail polish); (10) transgender/transsexual; (11) overall appearance (a catch-all category that including a general violation of appearance norms or grooming policy); and (12) other (miscellaneous appearance cases).

Legal Basis of Discrimination: We coded cases for whether plaintiffs charged sex, sexual orientation, religion, race/ethnicity, age, or disability as the legal basis of discrimination.

Defendant Status: We coded each employer for sector (public or private) and the type of industry, specifically (1) government service; (2) retail goods and services; (3) construction, manufacturing, and processing; (4) financial, administrative, and related services; (5) education; and (6) other organizations such as nonprofits, unions, and religious organizations.

Outcome: Most of the cases in our dataset were complex and involved many points of law. The final decision, then, usually involved a number of 
decisions on each point of law. Among other outcomes, points could have been awarded, remanded, vacated, affirmed, partly affirmed, reversed, or dismissed. We coded for whether the employee, in the final court decision, won a major point of law related to appearance.

\section{FINDINGS}

We begin with several broad descriptive findings in an attempt to map out some general patterns of appearance-related employment discrimination lawsuits. Here, we present basic trends about who sues, what kinds of cases have been heard by the courts over the years, the types of organizations that have been sued, and the legal outcomes of these suits. In these basic descriptive trends, we pay special attention to gender, that is, who sues by gender and who wins by gender. Next, we take a closer look at how courts have reinforced appearance norms in several key dimensions of appearance: hair; clothing, accessories, and tattoos; and makeup. As a whole, our analyses illustrate that federal courts not only reinforce appearance norms, they reinforce gendered appearance norms. This is particularly evident in a fourth set of cases we consider - gender nonconformity cases involving transgendered plaintiffs.

\section{General Trends}

Table 1 presents the number of cases (and percentages) for six appearance dimensions broken down by plaintiff gender (men, women, both, or transgender). The majority of cases were hair cases (60 or 30\%), followed by the clothing, accessories, and tattoo case category that comprises $22 \%$ of all cases. Claims filed by women and men were about equal at $41 \%$ and $43 \%$, respectively. Mixed gender suits comprise $8 \%$ of all cases, while the remaining $8 \%$ of cases were filed by individuals who identify as transgender.

We categorized organizations by type and nearly half of the 201 cases were in the retail goods and services industry $(n=95$, or $47.2 \%)$. This was followed by government services, a category that included all levels of public service ranging from city police and fire departments to state corrections and federal defense organizations. These cases comprise 59 or $29.4 \%$ of all cases. Twenty-two $(10.9 \%)$ cases were filed against employers in the financial and related industries, while 11 or $5.5 \%$ involved the construction, 
Table 1. Appearance Dimension of Cases by Plaintiff's Gender.

\begin{tabular}{|c|c|c|c|c|c|}
\hline $\begin{array}{l}\text { Appearance } \\
\text { Dimension }\end{array}$ & $\begin{array}{c}\text { Cases } \\
\text { Brought } \\
\text { by Men }\end{array}$ & $\begin{array}{c}\text { Cases } \\
\text { Brought } \\
\text { by Women }\end{array}$ & $\begin{array}{l}\text { Cases } \\
\text { Brought by } \\
\text { Men and } \\
\text { Women } \\
\text { Together }\end{array}$ & $\begin{array}{c}\text { Cases } \\
\text { Brought by } \\
\text { Transgendered } \\
\text { Individuals }\end{array}$ & $\begin{array}{c}\text { Total Number } \\
\text { of Cases (and } \\
\text { percentage) in } \\
\text { Each Appearance } \\
\text { Dimension }\end{array}$ \\
\hline $\begin{array}{l}\text { Clothing, } \\
\text { accessories, } \\
\text { tattoos }\end{array}$ & 8 & 34 & 2 & 0 & $44(21.9 \%)$ \\
\hline Hair & 52 & 8 & 0 & 0 & $60(29.8 \%)$ \\
\hline Obesity/overweight & 14 & 15 & 1 & 0 & $30(14.9 \%)$ \\
\hline Transgender & 0 & 0 & 0 & 16 & $16(8.0 \%)$ \\
\hline $\begin{array}{l}\text { Minimum weight/ } \\
\text { height }\end{array}$ & 2 & 14 & 9 & 0 & $25(12.4 \%)$ \\
\hline Other & 7 & 16 & 3 & 0 & $26(12.9 \%)$ \\
\hline $\begin{array}{l}\text { Total number of } \\
\text { cases (and } \\
\text { percentage) by } \\
\text { plaintiff's gender }\end{array}$ & $\begin{array}{c}83 \\
(41.3 \%)\end{array}$ & $\begin{array}{c}87 \\
(43.3 \%)\end{array}$ & $\begin{array}{c}15 \\
(7.5 \%)\end{array}$ & $\begin{array}{c}16 \\
(8.0 \%)\end{array}$ & $201(100.0 \%)$ \\
\hline
\end{tabular}

manufacturing, and processing industries. Lastly, $8(4.0 \%)$ plaintiffs worked in education (either colleges or schools) while the remaining $6(3.0 \%)$ cases were classified in other industries, including nonprofit, unions, or religious organizations.

We also classified each plaintiff by job type. Most cases (124 or 61.7\%) involve plaintiffs who work in service, sales, clerical, or administrative positions. This is followed by plaintiffs who work in blue collar positions such as laborers, mechanics, and truck drivers (39 or 19.4\%) and plaintiffs who occupy managerial or professional positions such as lawyers, doctors, and teachers $(37$ or $18.4 \%)$. In one case $(0.5 \%)$, employees of a hotel worked in multiple occupations, that is, clerical, managerial, and housekeeping (Davis v. Hospitality Services, LLC., 372 F.Supp.2d 641, 2005). Notably, rates of invoking sex discrimination were slightly higher among middle-tier service or administrative workers. Eighty-two of 124 (or 66\%) invoked sex discrimination compared to 18 of 37 (or 48.6\%) managerial or professional workers and 18 of 39 (or $46.2 \%$ ) of blue collar workers who filed suit based on sex discrimination.

Of these 201 cases, 118 (or 58.7\%) involve sex discrimination. Eleven of the 30 obesity/overweight cases involve sex discrimination (4 of which were successful). Of the minimum weight/height cases, 19 of the 25 cases (or $76 \%$ ) involve sex discrimination, 12 of which were successful. In the catch-all 
Table 2. Cases Won by Plaintiff's Gender and Appearance Dimension.

\begin{tabular}{|c|c|c|c|c|c|c|}
\hline $\begin{array}{l}\text { Appearance } \\
\text { Dimension }\end{array}$ & $\begin{array}{c}\text { Cases Won } \\
\text { by Men }\end{array}$ & $\begin{array}{l}\text { Cases Won } \\
\text { by Women }\end{array}$ & $\begin{array}{l}\text { Cases Won } \\
\text { by Men and } \\
\text { Women } \\
\text { Together }\end{array}$ & $\begin{array}{c}\text { Cases Won by } \\
\text { Transgendered } \\
\text { Individuals }\end{array}$ & $\begin{array}{c}\text { Total Cases } \\
\text { Won in Each } \\
\text { Appearance } \\
\text { Dimension }\end{array}$ & $\begin{array}{c}\text { Success } \\
\text { Rate }(\%)\end{array}$ \\
\hline $\begin{array}{l}\text { Clothing, } \\
\text { accessories, } \\
\text { tattoos }\end{array}$ & 3 & 10 & 1 & 0 & 14 & 31.8 \\
\hline Hair & 9 & 1 & 0 & 0 & 10 & 16.7 \\
\hline $\begin{array}{l}\text { Obesity/ } \\
\text { overweight }\end{array}$ & 2 & 6 & 0 & 0 & 8 & 25.6 \\
\hline Transgender & 0 & 0 & 0 & 4 & 4 & 25 \\
\hline $\begin{array}{l}\text { Minimum weight/ } \\
\text { height }\end{array}$ & 0 & 9 & 6 & 0 & 15 & 60 \\
\hline Other & 3 & 8 & 2 & 0 & 13 & 50 \\
\hline $\begin{array}{l}\text { Total number of } \\
\text { successful cases } \\
\text { (and success } \\
\text { rates) }\end{array}$ & $\begin{array}{l}17 \text { of } 83 \\
(20.5 \%)\end{array}$ & $\begin{array}{l}34 \text { of } 87 \\
(39.1 \%)\end{array}$ & $\begin{array}{l}9 \text { of } 15 \\
(60.0 \%)\end{array}$ & $\begin{array}{c}4 \text { of } 16 \\
(25.0 \%)\end{array}$ & 64 & 31.8 \\
\hline
\end{tabular}

"other" category, 16 of 26 cases $(61.5 \%)$ invoke sex discrimination, where only 7 of these cases involved successful plaintiffs. In the following section, we focus specifically on the remaining appearance dimensions, including rates of sex discrimination; as such, we do not elaborate on these dimensions here.

As indicated in Table 2, plaintiffs win about one-third of cases $(31.8 \%)$, ranging from $16.7 \%$ for hair cases to $60 \%$ of wins for plaintiffs who do not satisfy a weight or height requirement. Success appears to be more likely in cases of mixed-sex plaintiffs $(60 \%)$, while women's success rate $(39.1 \%)$ is generally higher than men's $(20.5 \%)$ - a winning rate comparable to transgendered plaintiffs at $25 \%$. Success rates are quite similar across occupational tiers. Managerial and professional plaintiffs saw success $29.7 \%$ of the time, compared to $32.3 \%$ and $33.3 \%$ for service/administrative/clerical workers and blue collar workers, respectively.

\section{Hair}

Federal courts deliberated on 60 hair-related cases between 1970 and 2008, with men initiating 52 (or $86.7 \%$ ) of these cases. This is somewhat ironic as most of these cases invoke Title VII, designed in part to protect women in the workplace. The sex difference in filing is particularly evident during the 1970s when 29 cases were filed by men and none by women. 


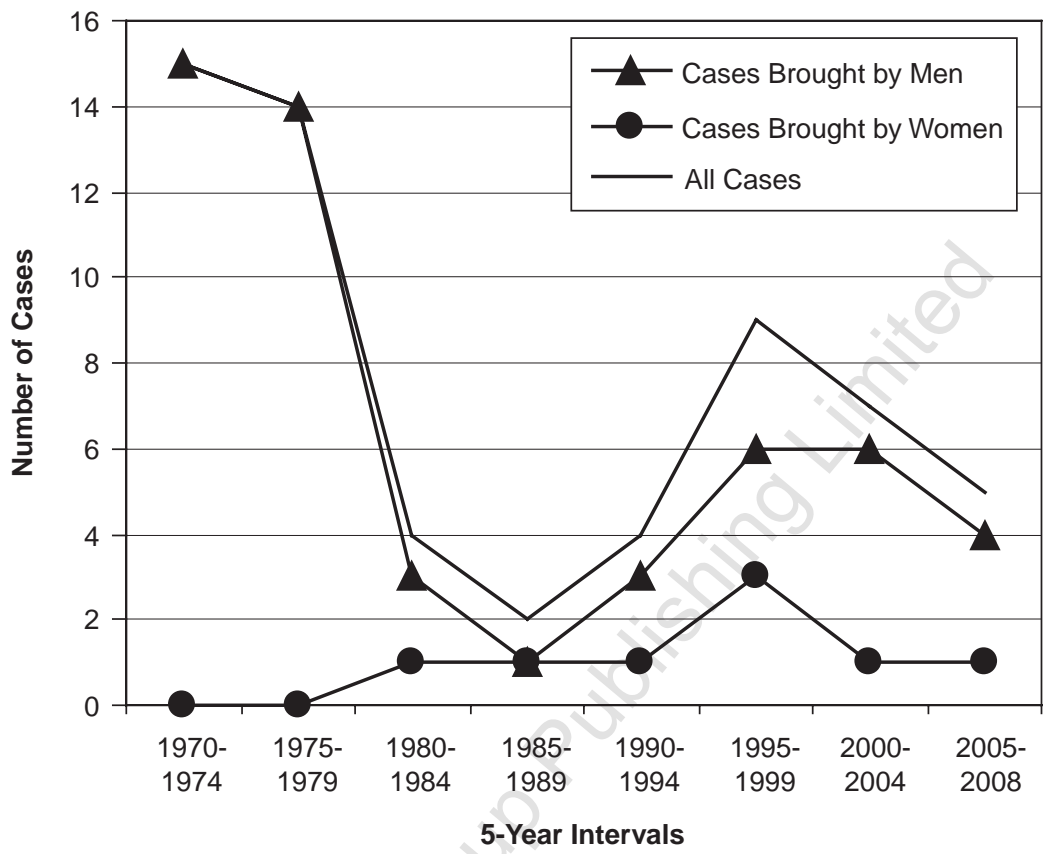

Fig. 1. Number of Hair-Related Cases by Gender.

The first woman-initiated hair case emerged in the 1980s when such cases were generally on the decline (Rogers $v$. American Airlines, Inc., 527 F.Supp. 229, 1981). Overall, as Fig. 1 indicates, we observe a general decline in cases from 1970 to 1996 and a small increase in cases in the late 1990s. Fig. 1 also makes clear the sex gap in lawsuits over this 38-year study period. Many factors may have contributed to this decline, including an overall relaxing of appearance norms including gendered hair norms in the workplace.

While plaintiffs who sued over hair-related issues accused employers of discrimination based on race or ethnicity, religion, age, and/or disability, about half of these hair cases involved claims of sex or gender discrimination ( 33 of 60 or $55 \%$ ). Of note, men filed the majority ( 29 or $87.8 \%$ ) of these 33 cases. In fact, 23 of these 33 cases $(69.7 \%)$ were filed before 1980 and a closer look at the data reveals that these early cases are primarily sex discrimination cases filed by men. In these cases, male plaintiffs charged that company policy or actions held men and women to different standards when it came to hair length (e.g., McConnell v. Mercantile Nat. Bank at Dallas, 389 F.Supp. 594, 1975) or facial hair such as sideburns and beards 
(e.g., Garrett v. City of Troy, 341 F.Supp. 633, 1972; Wofford v. Safeway Stores, Inc., 78 F.R.D. 460, 1978). These types of men's hair length and facial hair cases continued into the 1980s through to the mid-2000s, but unlike early sex discrimination cases, these later hair cases also involved other axes of discrimination such as religion (e.g., Booth v. Maryland, 327 F.3d 377, 2003; Brown v. F.L. Roberts \& Co., Inc., 419 F.Supp.2d 7, 2006) and race (African-American men and beards, e.g., Bradley v. Pizzaco of Nebraska, Inc., 7 F.3d 795, 1993).

In contrast to this narrow range of men's sex discrimination cases involving trimming head hair or removing facial hair, hair cases filed by female plaintiffs vary immensely. Some cases involved braids (e.g., Rogers $v$. American Airlines, Inc., 527 F.Supp. 229, 1981), other employees were told to improve their hair (e.g., Mannikko v. Harrah's Reno, Inc., 630 F.Supp. 191, 1986), that their hair was too long (e.g., Fortner v. State of Kan., 934 F.Supp. 1252, 1996), that their hair was too different and eye catching (e.g., Hollins v. Atlantic Co., Inc., 993 F.Supp. 1097, 1997), that their coiffure was out of style (Gonzalez v. El Dia, Inc., 304 F.3d 63, 2002), or were sanctioned for having an unusual hair color (e.g., Mathis v. Wachovia Bank, 255 Fed.Appx. 425, 2007). Only half (four of eight) of these cases allege sex discrimination while the remainder charge discrimination on grounds of race (e.g., Hollins v. Atlantic Co., Inc., 993 F.Supp. 1097, 1997), age and disability (e.g., Gonzalez v. El Dia, Inc., 304 F.3d 63, 2002), and religion (e.g., McGlothin v. Jackson Mun. Separate School Dist., 829 F.Supp. 853, 1992).

Of the 60 hair cases, only 10 case outcomes favored plaintiffs. Nine of these cases involve racial or religious discrimination and there is only one successful sex discrimination case. In Donohue v. Shoe Corp. of America (337 F.Supp. 1357, 1972), the plaintiff, a shoe salesman discharged for long hair, alleged sex discrimination as the employer permitted women to wear long hair. The court emphasized that unless sex is a bona fide occupational qualification (BFOQ), employers cannot refuse to retain an employee based on stereotyped characterizations of the sexes. The court's progressive thinking and justification are made clear in the ruling: "In our society we too often form opinions of people on the basis of skin color, religion, national origin, style of dress, hair length, and other superficial features. That tendency to stereotype people is at the root of some of the social ills that afflict the country, and in adopting the Civil Rights Act of 1964, Congress intended to attack these stereotyped characterizations so that people would be judged by their intrinsic worth" (Donohue, 337 F.Supp. 1359, 1972).

The decision in Donohue, however, is not the norm: hair cases alleging sex discrimination are generally unsuccessful. Dodge v. Giant Food, Inc. 
(488 F.2d 1333, 1973) is exemplary of these earlier sex discrimination hair cases filed by men. Similar to Donohue, in Dodge, male employees sued the food store chain alleging they were discharged or assigned unfavorable positions because they chose to wear their hair longer than what was permitted by Giant's grooming policy. The Court of Appeals, D.C. Circuit, held that grooming regulations that prohibited men from wearing long hair and provided that long hair on women must be secured did not violate Title VII. The court held that Giant did not limit employment opportunities based on hair length and the company did not impose disadvantages on one sex. The Court of Appeals thus affirmed the lower-court decision arguing that Giant's grooming regulations (that were developed in conjunction with both management and labor) were not unreasonable and that they applied to both sexes, regardless of race, the purposes of which was to "insure a neat and attractive, well-groomed male or female clerk." Indeed, the court's interpretation of such a clerk relied on traditional understandings of masculine appearance - where men should not possess long hair, a feature associated with femininity.

Similarly, sex discrimination hair cases filed by women tend to be unsuccessful. The hodgepodge of these cases involve many aspects of hair and appearance including charges of unclean and unkempt hair (Mannikko v. Harrah's Reno, Inc., 630 F.Supp. 191, 1986), an officer's hair length, bulk, and style (Fortner v. State of Kan., 934 F.Supp. 1252, 1996) and a female security guard whose hair was too long (Batson v. Powell, 21 F.Supp.2d 56, 1998). In all of these cases, for a variety of reasons, federal courts upheld the organization's ability to enforce restrictions on hair. A similar outcome occurred in Rogers v. American Airlines, Inc. (527 F.Supp. 229, 1981). However, this case is of particular interest, as the courts failed to recognize the intersection of sex and racial discrimination.

Rogers charged that American Airline's hair policy denied her the right to wear her hair in cornrows, thereby discriminating against her as a black woman. The court ruled that American Airlines' policy did not violate the 13th Amendment and did not discriminate against either women or blacks. Specifically, the courts argued that the grooming policy was even-handed insofar as it was neutrally applied to both men and women and individuals of all races. A key argument in the case was whether cornrows are worn as a matter of choice. In consideration of racial discrimination, the court concluded that all-braided hairstyles are different than Afro- or natural hairstyles, since they are not the product of natural hair but of artifice. In this way, the courts concluded that braids, a cultural practice, are presumably mutable. Although, as leading cultural defense scholar Renteln 
questions, "it is not obvious why traits chosen by ethnic groups should be less privileged than immutable traits. Whether innate or not, they are part of the cultural identity of the group in question" (2005, p. 143). This objection to cornrows, she theorizes, may be attributed in part to how cornrows stand in contrast to European aesthetics and are associated with the uncivil, unclean, resistance, slavery, and sexual provocation (2005, pp. 144-145). In addition, Caldwell's (1991) sociolegal analysis suggests that the outcome of Rogers was due in part to the court's failure to understand the intersection of race and gender since braids are an issue for black women specifically, and not all women, and not all blacks.

Indeed the relationship between racial and gender discrimination is complex, as legal scholar Onwuachi-Willig (2010) argues. The courts, she argues, have generally failed to protect black women because they do not fully understand black women's hair and the limited options they have for styling it. According to Onwuachi-Willig, African-American women whose employers ban braids, twists, and locks place an illegal and undue burden on black women. Unlike white women whose hair falls naturally, black women who face this ban have only three hair options: an Afro which is protected by law; a close cropped cut; or straightening through frequent chemically induced perms. For this reason, she argues, black women's hairstyles such as braids should also be protected by antidiscrimination laws.

In sum, hair cases that involve sex discrimination have been generally unsuccessful. In this way, employers have been able to enforce grooming standards that may be based on traditional notions of femininity and masculinity, a particularly complex matter when race is factored in.

\section{Clothing, Accessories, and Tattoos}

Between 1970 and 2008, 44 plaintiffs filed lawsuits against employers who violated what employees felt was a right to wear certain accessories, clothing, or tattoos. Accessory cases vary quite a bit, involving, among others, religious necklaces (e.g., Hedum v. Starbucks Corp., 546 F.Supp.2d 1017, 2008; Kreilkamp v. Roundy's, Inc., 428 F.Supp.2d 903, 2006), other religious paraphernalia such as a "Jesus Loves" T-shirt (e.g., Downing v. West Haven Board of Ed., 162 F.Supp.2d 19, 2001), facial jewelry (e.g., Cloutier v. Costco Wholesale, 311 F.Supp.2d 190, 2004), and union buttons (e.g., Scott v. Goodman, 961 F.Supp. 424, 1997). In this group, we also include religious head covering such as the hijab (e.g., EEOC v. Alamo Rent-A-Car LLC, 432 F.Supp.2d 1006, 2006). Thirty-four of these 44 cases 
$(77 \%)$ were filed by women and $8(18.2 \%)$ were filed by men. The other two cases were filed by both men and women. About half ( 25 of 44 , or $56.8 \%$ ) of these cases allege sex discrimination. Of these 25 sex discrimination cases, women filed 21, men filed 3, and one case was filed by women and men jointly. Notably, success rates for women and men are comparable. Only 14 of the total 44 cases $(32 \%)$ in this category saw plaintiff success, whereas 8 of $25(32 \%)$ sex discrimination cases were successful; 7 of $21(33.3 \%)$ female plaintiffs and 1 of $3(33.3 \%)$ male plaintiffs were successful.

In the majority of clothing and accessories cases, employers try to either impose certain kinds of clothing on employees or prevent them from wearing particular clothes or accessories. Legally, most businesses are allowed to use their employees' clothing and dress to achieve a particular "tone" or "image," and this "tone setting" or "branding" often results in different clothing requirements for men and women employees (Avery \& Crain, 2007; Bartlett, Harris, \& Rhode, 2002). Our data reveal that employers are about twice as likely to win clothing, accessories, and tattoo cases, including those where plaintiffs allege sex discrimination. Courts are only likely to side with employees under two general conditions (Levi, 2007): first, when employer policies sexually objectify women, thereby subjecting them to harmful effects such as verbal or physical sexual harassment, as in EEOC v. Sage Realty Corp. (507 F.Supp. 599, 1981) and, second, when an employer's policies require stricter standards for one group of workers than they do for another, as in Laffey v. Northwest Airlines (366 F.Supp. 763, 1973) or O'Donnell v. Burlington Coat Factory Warehouse (656 F.Supp. 263, 1987).

In EEOC v. Sage Realty Corp. (507 F.Supp. 599, 1981), the plaintiff was employed as a lobby attendant for a Manhattan office building. Every six months or so, lobby attendants were given new uniforms to wear, often related to a particular theme (uniforms included, for example, a tennis dress, blue jeans and cowboy boots, and a kilt outfit). In 1976, attendants were given "bicentennial" uniforms. These uniforms (for women only, as men ceased to be employed as lobby attendants the year prior) were essentially ponchos, snapped at each wrist, with light stitching tacked together at each side, but for the most part open on the sides. Attendants "were not permitted to wear a shirt or blouse, a Danskin, pants, or a skirt under the outfit," only sheer stockings and blue dancer pants. The uniform was thus quite revealing of women's thighs, buttocks, and the sides of breasts. While wearing the uniform on the job, the plaintiff found herself on the receiving end of a number of lewd remarks, gestures, and sexual propositions, so she complained to her employer and refused to wear the uniform again. She was eventually fired for noncompliance but won her case in court. 
Plaintiffs can also win cases when they demonstrate that the clothing or accessories requirements they were subject to were stricter than requirements for other groups. Like the Sage case, almost all examples of these successful cases involve differences between requirements for women and those for men. Two cases illustrate this type of appearance discrimination: Laffey v. Northwest Airlines (366 F.Supp. 763, 1973) and O'Donnell v. Burlington Coat Factory Warehouse (656 F.Supp. 263, 1987). In Laffey, the court struck down an airline's policy that required women flight attendants to wear contact lenses but allowed men to wear glasses. And in O'Donnell, the court ruled that allowing male sales clerks to wear shirts and ties while requiring that women in the same position wear "smocks" was discriminatory because it perpetuated sexual stereotypes.

Unsuccessful challenges to clothing or accessories requirements (or prohibitions) are plentiful and take many forms. Many of these decisions, some argue, end up legitimating the very stereotypes and social norms that led to the differential policies in the first place (Bartlett, 1994). The court held in Lanigan v. Bartlett and Co. Grain (466 F.Supp. 1388, 1979), for example, that prohibiting women from wearing pantsuits was nondiscriminatory, as the requirement did not interfere with employment opportunities and did not result in unequal burdens or negative consequences for women, as in Sage.

\section{Makeup}

In 2001 and 2002, three cases (Jespersen v. Harrah's Operating Co., Inc., 444 F.3d 1104, 2006; Romanello v. Shiseido Cosmetics America Ltd., not reported in F.Supp.2d, 2002; and Scott v. Sulzer Carbomedics, Inc., 141 F.Supp.2d 154, 2001) regarding some aspect of women's makeup were heard in federal courts. All three women plaintiffs alleged sex discrimination and all three cases were unsuccessful. A well-known case involving makeup that caught the attention of legal scholars and the media was Jespersen $v$. Harrah's. Jespersen was a bartender at Harrah's casino for over 20 years and received positive reviews for her performance. In 2000, Harrah's instituted a "Beverage Department Image Transformation" program requiring all bartenders to wear a standard uniform, be well groomed, and appealing to the eye. The program included sex-specific requirements: men had to keep short hair and trimmed fingernails and women were required to have their hair styled and to wear makeup daily. Jespersen complied with the appearance policy but for the makeup requirement, arguing that it would conflict with her self-image. She was terminated for noncompliance and subsequently sued Harrah's for gender discrimination under Title VII. 
The District Court granted summary judgment for Harrah's, finding that the burdens imposed by the policy were equal and that appearance standards were not impermissible gender stereotyping. This verdict was affirmed in the Ninth Circuit, en banc, in a 7-4 vote.

In Jespersen, the plaintiff attempted to make a case for sex discrimination following the 1989 Supreme Court case of Price Waterhouse v. Hopkins (490 U.S. 228, 1989) which held that an employer may not force employees to conform to gender-based sex stereotypes. Such attempts "can constitute impermissible discrimination 'based on sex' under Title VII" (Pizer, 2007, p. 292). Price Waterhouse involved a female employee who was denied promotion because her demeanor and conduct in the workplace was not sufficiently feminine. The Ninth Circuit, however, opted not to expand Price Waterhouse by extending gender stereotyping to an employee's gender appropriate attire.

Legal scholars have been critical of the case's outcome on many grounds. For example, Pizer (2007), who represented Jespersen in her appeal, argues that the courts considering a gender-specific rule should inquire into what the actual jobs at issue entail. In Jespersen, Harrah's justified its makeup rule by comparing its casinos to Disneyland. However, as Pizer points out, not all Disney employees are entertainers; similarly, Harrah's casino staff are not performers of any kind. Neglecting such distinctions are dangerous, particularly because customer preferences do not legitimate otherwise discriminatory company policies that might stem from the BFOQ exception. Given the four dissenting votes, some legal analysts have argued that it "is highly probable that this is not the last that employers have seen of this case. It, or one addressing the same issue, will eventually be heard before the Supreme Court" (Robinson, Franklin, Epermanis, \& Stowell, 2007, p. 292). Future plaintiffs who challenge grooming policies based on stereotypes need to provide evidence of disproportionate impact by sex. As a Harvard Law Review analysis indicates, future plaintiffs should respond by "presenting evidence of economic, physical, and psychological harms to prove that a requirement that women wear makeup imposes an unequal burden based on gender" (Anonymous, 2006, p. 651). Even so, as federal court decisions stands, courts have generally upheld gendered appearance norms such as the Jespersen requirement to wear makeup.

\section{Transgender}

Federal courts have heard 16 cases involving a transgender plaintiff, the first of which was heard in 1982. In many transgender cases, the failure to conform to gender stereotypes is central, and plaintiffs sued because they 
felt they were reprimanded for gender nonconformity. Some allege that their transgender appearance was the reason employers moved them to less visible positions (Dobre v. National R.R. Passenger Corp. (Amtrak) 850 F.Supp. 284, 1993), were not hired (Schroer v. Billington, 577 F.Supp.2d 293, 2008), or were discharged from their positions (Holloway v. Arthur Andersen \& Co., 566 F.2d 659, 1977). From Westlaw reports, 13 plaintiffs were identified as MTF and 3 as FTM. With the exception of two cases that alleged handicap discrimination (Blackwell v. U.S. Dept. of Treasury, 656 F.Supp. 713, 1986) and sexual orientation (Underwood v. Archer Management Services, Inc., 857 F.Supp. 96, 1994), all of these cases allege sex or gender discrimination. Although these transgender cases deal with appearance and particularly with appearance nonconformity, there is also a behavioral dimension to these cases. For example, in the sex discrimination case Etsitty v. Utah Transit Authority (502 F.3d 1215, 2007), Etsitty, an MTF individual, charged that she was terminated because she was a transsexual and because she failed to conform to their broad expectations of stereotypical male behavior. Indeed, many of these transgender cases involving cross-dressing provide strong evidence of the federal courts' reinforcement of the strict conception of masculine and feminine clothing to be donned by men and women, respectively. The majority (12 of 16 or $75 \%$ ) of cases involving transgender plaintiffs are unsuccessful. All four successful cases were sex or gender discrimination cases (three MTF plaintiffs, one FTM plaintiff).

Lopez v. River Oaks (542 F.Supp.2d 653, 2008) represents one of only a handful of successful cases filed by transgender plaintiffs. Lopez applied for a job with the defendant, a medical clinic. She interviewed for the position and believed prior to her interview that her potential employer knew she was transgendered, having informed friends who also worked at the medical clinic. On her application, she also indicated her legal name as Raul and an alternate name of Izza. Lopez filed employment discrimination action under Title VII after her prospective employer rescinded a job offer (on the basis of misrepresentation) upon discovery of her transgendered status. In court, the plaintiff successfully established that she did not misrepresent herself on her application and successfully argued a sex-stereotyping claim. In the court's words, "In this case, Lopez has pled, and developed facts in support of, a claim that River Oaks discriminated against her, not because she is transgendered, but because she failed to comport with certain River Oaks employees' notions of how a male should look" (542 F.Supp.2d 660, 2008). Indeed, the court noted that it could not ignore the plain language of Title VII and Price Waterhouse which do not distinguish between a transgendered plaintiff who fails to conform to traditional gender stereotypes and an 
effeminate man or macho woman. As such, there is no point at which a man becomes too effeminate (as say in the case of a transgendered individual) to warrant Title VII protection.

However, successful challenges to gender nonconformity transgender cases are the exception rather than the rule. For example, in Dobre $v$. National R.R. Passenger Corp. (Amtrak) (850 F.Supp. 284, 1993), the plaintiff was hired as a man, but after several months of employment began receiving hormone injections to transition to female. After informing the company, Amtrak responded by requesting Dobre to present a doctor's note in order to dress as a woman, requiring her to dress as a man, denying use of the women's restroom, addressing the plaintiff with a male name only, and transferring Dobre's desk out of public view. Dobre filed a complaint of sex discrimination under Title VII and sex-based and handicap discrimination in violation of state (Pennsylvania) statute. The courts denied the plaintiff's claim, arguing that Title VII does not protect transgendered individuals against discrimination because the term sex refers to anatomical sex, which is different than gender. Thus, through such justifications, courts have failed to acknowledge transgendered individuals' expressions as displayed though various dimensions of appearance such clothing and hairstyles.

\section{CONCLUSION}

The formal and informal regulation of employees' appearance is a routine component of organizational life. In this chapter, we analyzed appearancerelated employment discrimination lawsuits to examine ways in which organizations create and reinforce stereotypes that are gendered, raced, classed, and sexualized. Our focus on court deliberations and decisions allowed us to explore not only the gendered nature of appearance policies themselves, but also how such policies are supported, reinforced, codified, or, conversely, deemed unacceptable by the legal system. Almost all of the cases we discussed here show that organizations and courts are likely to support appearance norms that reinforce traditional ideas about femininity and masculinity.

Rather than being purely a concern of women, our data show that men and women are equally likely to sue their employers for appearance discrimination, and they were equally likely to file their suit as a sex discrimination claim. Women, however, are almost twice as likely to be successful in their claims, winning $39 \%$ of their cases, while men have only 
won $21 \%$ of their cases. Women's higher success rate is largely attributable to the kinds of cases they have brought (clothing cases and minimum height and weight) and the arguments they have made in justifying their claims. In both kinds of cases, women were likely to be successful when they were able to either demonstrate disparate impact, as in the minimum height and weight cases (not discussed here), in which a seemingly neutral policy regarding height or weight standards disproportionately impacted the ability of one group to successfully meet the standard, or when they were able to demonstrate an undue burden or hardship caused by disparate treatment, as in the clothing cases discussed previously. Men were most likely to sue over policies regarding their hair, and they also argued disparate treatment - they felt it was unfair to allow women to have long hair but not men. Yet they were unable to demonstrate that complying with the organizations' policies would result in an undue burden or hardship, leading to a very low success rate for these cases.

An examination of formal appearance policies and appearance lawsuits such as those discussed here has a great deal to offer gender, sexuality, and organizations scholars. Most sociological studies of appearance in the workplace have focused on individuals' motivations for complying with appearance norms and/or the informal rewards and sanctions associated with conformity or nonconformity (e.g., Dellinger \& Williams, 1997; Dozier, 2005; Gimlin, 1996; Kwan \& Trautner, 2009; Weitz, 2001). Few studies have examined actual organizational policies regarding employees' appearance or the social and legal consequences of such policies. Studying these formal policies is important for a number of reasons, including what we have shown in this chapter: men and women who refuse to comply with appearance norms face termination of their employment, promotion denials, lower wages, transfers, not being hired in the first place, and other workplace sanctions. We hope that our analyses here will help persuade other gender and organizations scholars to examine appearance policies as another important component of organizational life infused with ideas about femininity, masculinity, and beauty that ultimately lead to inequality, both in the workplace and in society overall.

There is a great deal left to explore in this burgeoning field. Future research should further explore the trends in appearance-related employment discrimination lawsuits that we have begun to outline here, particularly with an eye toward the combinations of factors that produce successful or unsuccessful challenges to appearance regulation. Researchers should also examine the diffusion of appearance policies - and challenges to such policies - among organizations and workers. How do previous 
challenges to appearance regulation, for example, affect the future policies that organizations make? In analyses not shown here, we note a rise in appearance discrimination lawsuits in the late 1990s and 2000s, yet this increase remains unexplained. Might the rise be due to an increase in workers' awareness of rights and general empowerment, particularly for disadvantaged or minority groups? Or perhaps there has been a rise in discriminatory policies in work organizations, or some other factors that might contribute to this rise. Ethnographic or trend data could also explore under what conditions men and women are likely to bring suit for appearance discrimination in the workplace. For example, researchers might explore whether there is a relationship between an employee's "token" status (Kanter, 1977) and their propensity to experience appearance policies as discriminatory, and whether tokenism operates differently for men and women in this circumstance.

Many legal scholars have called for appearance to become a protected legal category. Organizational appearance policies, they argue, emphasize standards of beauty which are, at their core, associated with youth, whiteness, heterosexuality, ability, and economic privilege. Thus, such policies compound other group disadvantages, "particularly those based on class, gender, race, ethnicity, disability, and sexual orientation" (Rhode, 2009 , p. 1052). Women in particular suffer from formal and informal appearance norms, as they not only face penalties for being too attractive as well as for being too unattractive, but most appearance norms also dictate that they spend inordinate (or at least unequal) amounts of time, money, effort, and energy to their appearance, whether they conform to conventional standards of beauty or not. Moreover, appearance standards that are gendered or sexualized, scholars argue, reinforce stereotypes and inequalities based on gender (see Bartlett, 1994; Rhode, 2009). Likewise, white and Protestant appearance standards obscure, and sometimes eliminate, cultural and ethnic diversity as well as individual expression. Such legal changes may be an important step in safeguarding workers and protecting workplaces from charges of discriminatory practices.

\section{NOTES}

1. We performed two separate searches. One search gave us all the cases that fell under Westlaw's 78k1177 category (this code translates into: "Civil Rights Employment Practices - Personal appearance; hair and grooming"). The second search asked for cases that fell into "Civil Rights - Employment Practices" other 
than the "Personal appearance" category that used at least one of our search terms in the synopsis or digest fields. We used these fields in order to only obtain cases in which our search terms were significant. The synopsis refers to the summary paragraph written by Westlaw that appears at the beginning of each case, and digest refers to the headnotes and topics in the case. Our search terms were as follows: (obes! overweight fat height hair! beard "facial hair" groom! make-up "make up" teeth smile cloth! dress! "dress code" sexy feminin! masculin! "younger looking" skin tattoo! jewel! "physical appearance" "personal appearance" beaut! ugly! unattractive! cosmetic! "head covering" garb "weight requirement" earring "sex stereotype" "gender stereotype" "weight discrimination" moustache "body piercing!" eyeglass! pretty transsex! dreadlocks). An exclamation point at the end of a word (or partial word) asks Westlaw to return results that use any ending/form of that word. A phrase in quotation marks asks Westlaw to search for the exact phrase.

2. We removed an additional 51 search terms from our query, as they (a) yielded no results; (b) yielded mostly unrelated results; or (c) yielded results that were entirely duplicated using other search terms. These 51 search terms were accessor! breast kufi skinny afro "breast size" lingerie skirt! alopecia burqa "masculine stereotype" tall appearance chadri necklace thin bald fashion "older looking" thong bindi fashionable "panty lines" tooth birthmark "feminine stereotype" "personal hygiene" veil body flamboyant "physical characteristics" weight "body art" "garb law" Rastafarian wig "body shape" "gender dysphoria" sari wrinkl! "body size" "gender norms" sexi! yamika "body weight" "head scarf" shawl younger braids hijab short.

\section{ACKNOWLEDGMENTS}

We are grateful to the Baldy Center for Law \& Social Policy at the University at Buffalo for their support of this project. Marcia Zubrow and Beth Adelman at the University at Buffalo and Mon Yin Lung at the University of Houston provided invaluable law library and Westlaw assistance. Amy Natiella and Keiisha Pillai assisted with data coding and data entry. Finally, we wish to thank Christine Williams, Kirsten Dellinger, and an anonymous reviewer for their insightful and helpful comments on an earlier draft. All remaining mistakes are ours.

\section{REFERENCES}

Acker, J. (1990). Hierarchies, jobs, bodies: A theory of gendered organizations. Gender \& Society, 4, 139-158.

Anonymous. (2006). Title VII - Gender discrimination - Ninth circuit holds that women can be fired for refusing to wear makeup - Jespersen v. Harrah's Operating Co., 444 F.3d 1004 (Ninth Cir.2006) (en banc). Harvard Law Review, 120(2), 651-658. 
Avery, D. (2007). The great American makeover: The sexing up and dumbing down of women's work after Jespersen v. Harrah's Operating Company, Inc. University of San Francisco Law Review, 42, 299-328.

Avery, D., \& Crain, M. (2007). Branded: Corporate image, sexual stereotyping, and the new face of capitalism. Duke Journal of Gender, Law \& Policy, 14, 13-123.

Bartlett, K. T. (1994). Only girls wear barrettes: Dress and appearance standards, community norms, and workplace equality. Michigan Law Review, 92, 2541-2582.

Bartlett, K. T., Harris, A. P., \& Rhode, D. L. (2002). Gender and law: Theory, doctrine, commentary (3rd ed). New York: Aspen.

Britton, D. M. (2000). The epistemology of the gendered organization. Gender \& Society, 14, 418-434.

Britton, D. M., \& Logan, L. (2008). Gendered organizations: Progress and prospects. Sociology Compass, 2, 107-121.

Caldwell, P. M. (1991). A hair piece: Perspectives on the intersection of race and gender. Duke Law Journal, 2, 365-396.

Chapkis, W. (1986). Beauty secrets: Women and the politics of appearance. Boston, MA: South End Press.

Dellinger, K., \& Williams, C. L. (1997). Makeup at work: Negotiating appearance rules in the workplace. Gender \& Society, 11, 151-177.

Dozier, R. (2005). Beards, breasts, and bodies: Doing sex in a gendered world. Gender \& Society, 19, 297-316.

Gimlin, D. L. (1996). Pamela's place: Power and negotiation in the hair salon. Gender \& Society, 10, 505-526.

Guthrie, D., \& Roth, L. M. (1999). The state, courts, and maternity policies in U.S. organizations: Specifying institutional mechanisms. American Sociological Review, 64, 41-63.

Hammermesh, D. S., \& Biddle, J. E. (1994). Beauty and the labor market. American Economic Review, 84, 1174-1194.

Hosoda, M., Stone-Romero, E. F., \& Coats, G. (2003). The effects of physical attractiveness on job-related outcomes: A meta-analysis of experimental studies. Personnel Psychology, 56, 431-462.

Hurley-Hanson, A. E., \& Giannontonio, C. M. (2006). Recruiters' perception of appearance: The stigma of image norms. Equal Opportunities International, 25(6), 450-463.

Kanter, R. M. (1977). Men and women of the corporation. New York: Basic Books.

Kwan, S., \& Trautner, M. N. (2009). Beauty work: Individual and institutional rewards, the reproduction of gender, and questions of agency. Sociology Compass, 3, 49-71.

Levi, J. L. (2007). Some modest proposals for challenging established dress code jurisprudence. Duke Journal of Gender Law \& Policy, 14, 243-255.

McEvoy, S. A. (1992). Fat chance: Employment discrimination against the overweight. Labor Law Journal, 43(1), 3-14.

Onwuachi-Willig, A. (2010). Another hair piece: Exploring new strands of analysis under title VII. Georgetown Law Journal, 98, 1079-1132.

Pierce, J. (1995). Gender trials: Emotional lives in contemporary law firms. Berkeley, CA: University of California Press.

Pizer, J. (2007). Facial discrimination: Darlene Jespersen's fight against the Barbie-fication of bartenders. Duke Journal of Gender, Law \& Policy, 14, 285-318.

Pope, H. G., Jr., Phillips, K. A., \& Olivardia, R. (2000). The Adonis complex: The secret crisis of male body obsession. New York: The Free Press. 
Quinn, B. A. (2002). Sexual harassment and masculinity: The power and meaning of 'girl watching'. Gender \& Society, 16, 386-402.

Renteln, A. D. (2005). The cultural defense. New York: Oxford University Press.

Rhode, D. L. (2009). The injustice of appearance. Stanford Law Review, 61, 1033-1101.

Robinson, R. K., Franklin, G. M., Epermanis, K., \& Stowell, N. F. (2007). Employee appearance policies and title VII: New challenges for sex differentiated standards. Journal of Individual Employment Rights, 12, 287-302.

Roth, L. M. (2006). Selling women short: Gender and money on Wall Street. Princeton, NJ: Princeton University Press.

Schrock, D., \& Schwalbe, M. (2009). Men, masculinity, and manhood acts. Annual Review of Sociology, 35, 277-295.

Weitz, R. (2001). Women and their hair: Seeking power through resistance and accommodation. Gender \& Society, 15, 667-686.

West, C., \& Zimmerman, D. H. (1987). Doing gender. Gender \& Society, 1, 125-151.

Williams, C. L. (1992). The glass escalator: Hidden advantages for men in the 'female' professions. Social Problems, 39, 253-367. 